\title{
Effect of Copper and Zinc Ions on Struvite Nucleation and Crystal Growth Kinetics in Various Process Environments
}

\author{
Nina Hutnik ${ }^{1}$, Anna Stanclik ${ }^{1}$, Krzysztof Piotrowski²*, Andrzej Matynia ${ }^{1}$ \\ ${ }^{1}$ Wroclaw University of Science and Technology, Faculty of Chemistry, Wroclaw, Poland \\ ${ }^{2}$ Silesian University of Technology, Department of Chemical Engineering and Process Design, Gliwice, Poland
}

Received: 19 February 2019

Accepted: 21 July 2019

\begin{abstract}
We determined the kinetic parameters of struvite continuous reaction crystallization in aqueous solutions of phosphate(V) ions with selected impurities: copper or/and zinc ions. The simplified kinetic model for ideal continuous MSMPR (mixed suspension mixed product removal) crystallizer - SIG (size-independent growth) model frame was adopted for the calculations. Nuclei population densities, nucleation rates and crystal linear growth rates of nuclei up to macroscopic size range were determined based on crystal size distributions of the solid products. We concluded that within the assumed process parameter ranges the linear growth rate of struvite crystals varied within the $4 \cdot 11 \cdot 10^{-9}-1.62 \cdot 10^{-8} \mathrm{~m} / \mathrm{s}$ range in the presence of copper ions and within the $4.53 \cdot 10^{-9}-1.51 \cdot 10^{-8} \mathrm{~m} / \mathrm{s}$ range in the presence of zinc ions. Nucleation rate, however, varied within the $6.8 \cdot 10^{7}-2.0 \cdot 10^{9} 1 /\left(\mathrm{sm}^{3}\right)$ and $6.3 \cdot 10^{7}-1.7 \cdot 10^{9} 1 /\left(\mathrm{sm}^{3}\right)$ ranges, appropriately. These are large differences demonstrating the significant influence of impurities together with process technological parameters on struvite continuous reaction crystallization kinetics and thus in consequence - on the manufactured product quality. We also experimentally proved that the effect of copper ions on struvite reaction crystallization is more advantageous than zinc ions action.
\end{abstract}

Keywords: struvite, copper, zinc, continuous reaction crystallization kinetics, wastewater, phosphorus recycling

\section{Introduction}

Copper and zinc ions are impurities commonly present in wastewaters from the phosphoric acid and phosphorus mineral fertilizer industries [1]. Depending on the specific wastewater generation place, concentration of phosphate(V) ions can vary from

*e-mail: Krzysztof.Piotrowski@polsl.pl
0.2 up to even 1.0 mass $\%$ of $\mathrm{PO}_{4}{ }^{3-}$, whereas the discussed impurities concentrations oscillate from 0.2 to $0.5 \mathrm{mg} \mathrm{Cu} / \mathrm{kg}$ wastewater and from 0.2 to $2.0 \mathrm{mg} \mathrm{Zn} / \mathrm{kg}$ wastewater $[1,2]$. Recovery of phosphate $(\mathrm{V})$ ions from such wastewater types (phosphorus recycling) is fully motivated ecologically, technically and economically [2]. Technologically the process is based on the binding of $\mathrm{PO}_{4}{ }^{3-}$ ions in a form of sparingly soluble magnesium and ammonium salt $\mathrm{MgNH}_{4} \mathrm{PO}_{4} \cdot 6 \mathrm{H}_{2} \mathrm{O}$, struvite, MAP [3]. The most common process runs in an alkaline environment after contacting phosphate(V) ions with 
magnesium and ammonium ions, in an appropriately designed crystallizer [4]. However, impurities copresent in wastewater also take part in the struvite reaction crystallization process. These influence not only nucleation and struvite crystal growth, but also its physical form. Some of them co-precipitate in a form of phosphates (like calcium ions) or hydroxides (especially iron, aluminium, zinc, copper ions) [5]. Market value of struvite (quality) can be thus lower, while MAP applicability as a mineral fertilizer is more or less restricted $[6,7]$. It is an important technological aspect that cannot be neglected. The research results covering the effects of the presence and concentration of $\mathrm{Cu}^{2+}$ and $\mathrm{Zn}^{2+}$ ions, together with the influences of selected process parameters on struvite reaction crystallization in a laboratory DT MSMPR (draft tube, mixed suspension mixed product removal) continuous crystallizer type with propeller mixer are presented and discussed. Based on crystal size distributions (CSDs) of the manufactured products, the kinetic parameters of struvite continuous reaction crystallization were estimated. The SIG (size-independent growth) kinetic model frame was applied [8, 9]. Research results demonstrating and quantifying the effects of copper $[10,11]$ and zinc ions $[12,13]$ on the quality of struvite crystals manufactured in their presence, as well as on the chemical and phase compositions of final products, were also introduced into discussion.

\section{Experimental}

An aqueous solution of ammonium dihydrogenphosphate(V) $\quad \mathrm{NH}_{4} \mathrm{H}_{2} \mathrm{PO}_{4}, \quad$ magnesium chloride $\mathrm{MgCl}_{2} \cdot 6 \mathrm{H}_{2} \mathrm{O}$ and copper chloride $\mathrm{CuCl}_{2} \cdot 2 \mathrm{H}_{2} \mathrm{O}$ or/and zinc chloride $\mathrm{ZnCl}_{2}$ was used as the crystallizer feed. The solution was prepared in an external mixer using the substances in crystalline forms presented above (p.a., POCh Gliwice, Poland) and deionised water (Barnstead-NANOpure DIamond). Concentrations of phosphate $(\mathrm{V})$ ions were assumed to be $0.20,0.445$ or 1.0 mass \%, which represents their typical values in wastewaters from the phosphorus mineral fertilizer industry $[1,2]$. Concentrations of other struvite synthesis substrates were the consequence of the assumed molar ratio $\mathrm{PO}_{4}^{3-}: \mathrm{Mg}^{2+}: \mathrm{NH}_{4}^{+}=1: 1: 1$ (stoichiometry) or 1:1.2:1 (20\% magnesium ions excess) (Table 1). Concentrations of copper or zinc ions in a feed were $0.2,0.3$ or $0.5 \mathrm{mg}$ $\mathrm{Cu}^{2+} / \mathrm{kg}$ of solution, or $0.2,0.5$ or $2.0 \mathrm{mg} \mathrm{Zn}{ }^{2+} / \mathrm{kg}$ of solution and, additionally, $0.25 \mathrm{mg} \mathrm{Cu}{ }^{2+} / \mathrm{kg}$ of solution and/or $2.2 \mathrm{mg} \mathrm{Zn}{ }^{2+} / \mathrm{kg}$ of solution [2]. Crystallizer was provided with such defined feed, together with aqueous solution of sodium hydroxide $(20$ mass $\% \mathrm{NaOH})$ dosing in proportion assuring the assumed, controlled $\mathrm{pH}$ of struvite continuous reaction crystallization environment. The tests ran at temperature $298 \pm 0.2 \mathrm{~K}$, for $\mathrm{pH} \mathrm{9,10}$ or 11 $( \pm 0.1)$ and arranging mean residence time of suspension in a crystallizer $\tau 900$ or $3600 \mathrm{~s}( \pm 20 \mathrm{~s})$. Characteristic of the crystallizer unit, details of its work mode, method of determination of crystal size distribution (CSD) and its recalculation into corresponding population density distribution (PDD, $n_{\mathrm{i}}(L), L-$ crystal size), estimation of struvite crystal shape (crystal length to width ratio $L_{\mathrm{a}} / L_{\mathrm{b}}$, crystal shape coefficient $k_{\mathrm{v}}$ ) and analytical determination of chemical/phase composition of the products are presented elsewhere [10-14]. Selected experimental results [10-13] were supplemented with new measurements and presented together in Table 2. Exemplary scanning microscope images of struvite crystals manufactured in the presence of copper [11] or zinc [12] ions are demonstrated in Fig. 1.

Effects of the impurities present on struvite crystal shapes are thus clearly demonstrated. One can, however, notice distinct differences between the individual effects of copper and zinc ions. The quantitative approach for these differences (crystal length $L_{\mathrm{a}}$ to width $L_{\mathrm{b}}$ ratio, crystal shape coefficient $k_{\mathrm{v}}=V_{\text {crystal }} / L^{3}$ ) is presented in Table $3\left(\mathrm{Cu}^{2+}\right.$ ions) and in Table $4\left(\mathrm{Zn}^{2+}\right.$ ions). Some reference data for the comparison of size and shape of struvite crystals produced from aqueous solution without impurities are presented in [14].

Simplifying assumptions applied for the rigorous MSMPR crystallizer characteristic and for the SIG kinetic model, together with the method of calculated data interpretation, are presented in [14]. For these assumptions, population density distribution of product crystals can be presented in the following form (1):

Table 1. Chemical composition of synthetic wastewater.

\begin{tabular}{|c|c|c|c|c|c|c|}
\hline \multirow{2}{*}{$\begin{array}{l}\text { Molar proportion of substrate } \\
\text { ions in a feed } \\
\mathrm{PO}_{4}^{3-}: \mathrm{Mg}^{2+}: \mathrm{NH}_{4}^{+}\end{array}$} & \multicolumn{6}{|c|}{ Concentration of: } \\
\hline & $\begin{array}{c}\mathrm{PO}_{4}^{3-} \\
\text { mass \% }\end{array}$ & $\begin{array}{c}\mathrm{Mg}^{2+} \\
\operatorname{mass} \%\end{array}$ & $\begin{array}{c}\mathrm{NH}_{4}^{+} \\
\text {mass \% }\end{array}$ & $\begin{array}{c}\mathrm{Cu}^{2+} \\
\mathrm{mg} / \mathrm{kg}\end{array}$ & & $\begin{array}{c}\mathrm{Zn}^{2+} \\
\mathrm{mg} / \mathrm{kg}\end{array}$ \\
\hline \multirow{2}{*}{$1: 1: 1$} & 0.20 & 0.0512 & 0.0380 & 0.2 & or & 0.5 \\
\hline & 1.0 & 0.256 & 0.190 & $0.2,0.3,0.5$ & or & $0.2,0.5,2.0$ \\
\hline \multirow{4}{*}{$1: 1.2: 1$} & 0.20 & 0.0614 & 0.0380 & $0.2,0.25$ & or & 2.2 \\
\hline & 0.445 & 0.137 & 0.0846 & 0.25 & or & 2.2 \\
\hline & 0.445 & 0.137 & 0.0846 & 0.25 & and & 2.2 \\
\hline & 1.0 & 0.307 & 0.190 & 0.2 & or & 0.5 \\
\hline
\end{tabular}


Table 2. Characteristics of struvite crystals produced from aqueous solution containing phosphate(V) and copper(II) [10, 11] or zinc(II) $[12,13]$ ions at $298 \mathrm{~K}$.

\begin{tabular}{|c|c|c|c|c|c|c|c|c|c|}
\hline \multirow{3}{*}{ No. } & \multicolumn{5}{|c|}{ Process parameters } & \multicolumn{4}{|c|}{ Crystal size distribution $^{\mathrm{a}}$} \\
\hline & {$\left[\mathrm{PO}_{4}{ }^{3-}\right]_{\mathrm{RM}}$} & {$\left[\mathrm{Cu}^{2+}\right]_{\mathrm{RM}}$} & {$\left[\mathrm{Zn}^{2+}\right]_{\mathrm{RM}}$} & $\mathrm{pH}$ & $\tau$ & $L_{\mathrm{m} \mathrm{Cu}}$ & $L_{\mathrm{m} \mathrm{Zn}}$ & $\mathrm{CV}_{\mathrm{Cu}}$ & $\mathrm{CV}_{\mathrm{Zn}}$ \\
\hline & $\operatorname{mass} \%$ & $\mathrm{mg} / \mathrm{kg}$ & $\mathrm{mg} / \mathrm{kg}$ & - & s & $\mu \mathrm{m}$ & $\mu \mathrm{m}$ & $\%$ & $\%$ \\
\hline \multicolumn{10}{|c|}{ Molar proportion of substrate ions in a feed: $\left[\mathrm{PO}_{4}{ }^{3-}\right]_{\mathrm{RM}}:\left[\mathrm{Mg}^{2+}\right]_{\mathrm{RM}}:\left[\mathrm{NH}_{4}^{+}\right]_{\mathrm{RM}}=1: 1: 1$} \\
\hline 1 & 1.0 & 0.2 & 0.2 & 9 & 900 & 27.5 & 31.4 & 92.9 & 84.0 \\
\hline 2 & 1.0 & 0.3 & 0.5 & 9 & 900 & 28.8 & 29.3 & 80.4 & 90.0 \\
\hline 3 & 1.0 & 0.5 & 2.0 & 9 & 900 & 29.3 & 23.1 & 84.5 & 92.1 \\
\hline 4 & 1.0 & 0.2 & 0.2 & 10 & 900 & 21.5 & 23.8 & 86.6 & 92.0 \\
\hline 5 & 1.0 & 0.5 & 0.5 & 10 & 900 & 23.7 & 22.3 & 86.6 & 91.7 \\
\hline 6 & 1.0 & 0.2 & 0.2 & 11 & 900 & 18.8 & 22.0 & 82.1 & 92.8 \\
\hline 7 & 1.0 & 0.5 & 0.5 & 11 & 900 & 19.0 & 18.0 & 95.7 & 92.1 \\
\hline 8 & 1.0 & 0.2 & 0.2 & 9 & 3600 & 39.7 & 41.0 & 96.4 & 88.3 \\
\hline 9 & 1.0 & 0.5 & 0.5 & 9 & 3600 & 41.0 & 40.8 & 82.6 & 93.4 \\
\hline 10 & 0.20 & 0.2 & 0.5 & 9 & 900 & 31.1 & 31.0 & 93.9 & 91.5 \\
\hline \multicolumn{10}{|c|}{ Molar proportion of substrate ions in a feed: $\left[\mathrm{PO}_{4}^{3-}\right]_{\mathrm{RM}}:\left[\mathrm{Mg}^{2+}\right]_{\mathrm{RM}}:\left[\mathrm{NH}_{4}^{+}\right]_{\mathrm{RM}}=1: 1.2: 1$} \\
\hline 11 & 1.0 & 0.2 & 0.5 & 9 & 900 & 28.8 & 29.4 & 92.8 & 85.9 \\
\hline 12 & 0.20 & 0.2 & 0.5 & 9 & 900 & 33.0 & 32.9 & 90.2 & 90.3 \\
\hline
\end{tabular}

a After drying, without water washing of solid phase on a filter

Test No. 9 ( $\mathrm{Cu}^{2+}$ ions) and tests No. 5, 7, 9-12 ( $\mathrm{Zn}^{2+}$ ions $)$ - present study

Solid phase content in a product suspension $M_{\mathrm{T}} 24.3 \pm 0.5 \mathrm{~kg} / \mathrm{m}^{3}$ (tests No. 1-9, 11) and $M_{\mathrm{T}} 4.7 \pm 0.2 \mathrm{~kg} / \mathrm{m}^{3}$ (tests No. 10, 12)

$L_{\mathrm{m}}$ - mean crystal size, $L_{\mathrm{m}}=\Sigma x_{\mathrm{i}} L_{\mathrm{i}}$, where: $x_{\mathrm{i}}$ - mass fraction of crystals of mean fraction size $L_{\mathrm{i}} ; \mathrm{CV}=100\left(L_{84}-L_{16}\right) /\left(2 L_{50}\right)$, where:

$L_{84}, L_{16}, L_{50}$ - crystal sizes corresponding to: 84,16 and 50 mass $\%$ undersize fractions in cumulative distribution

$$
n(L)=n_{0} \exp \left(-\frac{L}{G_{\tau}}\right)
$$

...from which one can calculate linear crystal growth rate $G$ (see Figs. 2 a-b). Knowing $G$ and nuclei population density $n_{0}$, nucleation rate $B$ can be calculated with Eq. (2):

$$
B=n_{0} G
$$

\section{Results and Discussion}

Exemplary experimental population density distributions of struvite crystals manufactured in the presence of copper $(0.2 \mathrm{mg} / \mathrm{kg}$, Fig. 2a) and zinc $(0.2 \mathrm{mg} / \mathrm{kg}$, Fig. $2 \mathrm{~b})$ ions are presented in Fig. 2.

From these distribution courses, presented in $\ln n-L$ coordinates it results, that for larger struvite particles $(L>40 \mu \mathrm{m})$ such relations can be with satisfactory accuracy approximated with linear
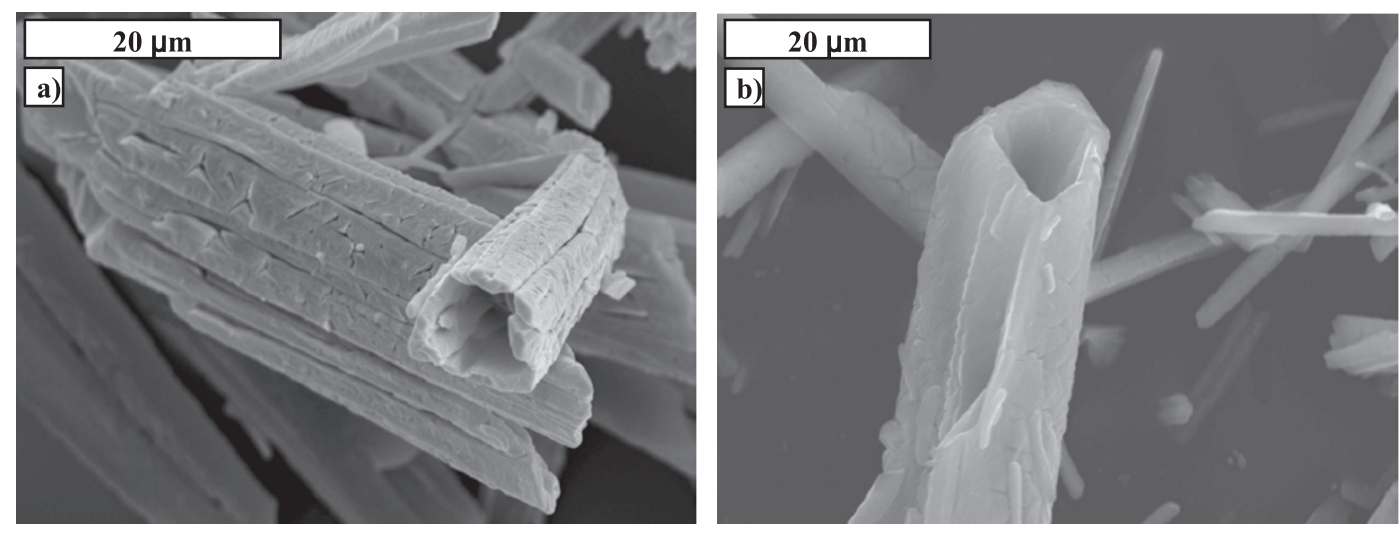

Fig. 1. Details of habit and surface morphology of struvite crystals produced in the presence of copper(II) ions a) and zinc(II) ions b). 
Table 3. Effect of copper ions on struvite nucleation rate $B$ and crystal linear growth rate $G$ in a continuous reaction crystallization process; kinetic parameters calculated with SIG MSMPR model (for process conditions see Table 2).

\begin{tabular}{|c|c|c|c|c|c|c|}
\hline \multirow{3}{*}{ No. } & \multicolumn{6}{|c|}{ Kinetic parameter values of the process (SIG MSMPR model) } \\
\hline & $n(L) *$ for $L>40 \mu \mathrm{m}$ & $\mathrm{R}^{2}$ & $L_{\mathrm{a}} / L_{\mathrm{b} \mathrm{Cu}}$ & $k_{\mathrm{v}}$ & $\mathrm{G}$ & $B^{*}$ \\
\hline & & & - & - & $(\mathrm{m} / \mathrm{s})$ & $\left(1 /\left(\mathrm{sm}^{3}\right)\right)$ \\
\hline \multicolumn{7}{|c|}{ Molar proportion of substrate ions in a feed: $\left[\mathrm{PO}_{4}^{3-}\right]_{\mathrm{RM}}:\left[\mathrm{Mg}^{2+}\right]_{\mathrm{RM}}:\left[\mathrm{NH}_{4}^{+}\right]_{\mathrm{RM}}=1: 1: 1$} \\
\hline 1 & $n=6.978 \cdot 10^{16} \exp \left(-8.767 \cdot 10^{4} L\right)$ & 0.999 & 6.6 & 0.018 & $1.27 \cdot 10^{-8}$ & $8.9 \cdot 10^{8}$ \\
\hline 2 & $n=6.310 \cdot 10^{16} \exp \left(-8.465 \cdot 10^{4} L\right)$ & 0.997 & 6.6 & 0.018 & $1.31 \cdot 10^{-8}$ & $8.3 \cdot 10^{8}$ \\
\hline 3 & $n=4.387 \cdot 10^{16} \exp \left(-8.103 \cdot 10^{4} L\right)$ & 0.996 & 6.5 & 0.019 & $1.37 \cdot 10^{-8}$ & $6.0 \cdot 10^{8}$ \\
\hline 4 & $n=1.287 \cdot 10^{17} \exp \left(-1.076 \cdot 10^{5} L\right)$ & 0.998 & 5.2 & 0.029 & $1.03 \cdot 10^{-8}$ & $1.3 \cdot 10^{9}$ \\
\hline 5 & $n=9.738 \cdot 10^{16} \exp \left(-9.771 \cdot 10^{4} L\right)$ & 0.996 & 5.2 & 0.029 & $1.14 \cdot 10^{-8}$ & $1.1 \cdot 10^{9}$ \\
\hline 6 & $n=2.193 \cdot 10^{17} \exp \left(-1.203 \cdot 10^{5} L\right)$ & 0.997 & 4.9 & 0.033 & $9.24 \cdot 10^{-9}$ & $2.0 \cdot 10^{9}$ \\
\hline 7 & $n=1.354 \cdot 10^{17} \exp \left(-1.125 \cdot 10^{5} L\right)$ & 0.997 & 4.8 & 0.034 & $9.88 \cdot 10^{-9}$ & $1.4 \cdot 10^{9}$ \\
\hline 8 & $n=2.190 \cdot 10^{16} \exp \left(-6.756 \cdot 10^{4} L\right)$ & 0.994 & 7.7 & 0.013 & $4.11 \cdot 10^{-9}$ & $9.0 \cdot 10^{7}$ \\
\hline 9 & $n=2.459 \cdot 10^{16} \exp \left(-6.406 \cdot 10^{4} L\right)$ & 0.989 & 7.7 & 0.013 & $4.34 \cdot 10^{-9}$ & $1.1 \cdot 10^{8}$ \\
\hline 10 & $n=6.102 \cdot 10^{15} \exp \left(-7.579 \cdot 10^{4} L\right)$ & 0.996 & 6.7 & 0.017 & $1.47 \cdot 10^{-8}$ & $9.0 \cdot 10^{7}$ \\
\hline \multicolumn{7}{|c|}{ Molar proportion of substrate ions in a feed: $\left[\mathrm{PO}_{4}^{3-}\right]_{\mathrm{RM}}:\left[\mathrm{Mg}^{2+}\right]_{\mathrm{RM}}:\left[\mathrm{NH}_{4}^{+}\right]_{\mathrm{RM}}=1: 1.2: 1$} \\
\hline 11 & $n=4.244 \cdot 10^{16} \exp \left(-8.051 \cdot 10^{4} L\right)$ & 0.996 & 6.6 & 0.018 & $1.38 \cdot 10^{-8}$ & $5.8 \cdot 10^{8}$ \\
\hline 12 & $n=4.217 \cdot 10^{15} \exp \left(-6.859 \cdot 10^{4} L\right)$ & 0.995 & 6.6 & 0.018 & $1.62 \cdot 10^{-8}$ & $6.8 \cdot 10^{7}$ \\
\hline
\end{tabular}

$*$ for $k_{\mathrm{v}}=1$

$\mathrm{R}^{2}$ for linear segment only

function (confirming thus validity of SIG kinetic model approach). This was clearly observed in the case of both impurity actions on $n(L)$ distribution of struvite. Determined using Eq. (1) parameters of population density distribution for struvite crystals of size $L>40 \mu \mathrm{m}$ for each process conditions set, as well as calculated on this basis $G$ (Eq. (1)) and $B^{*}$ (Eq. (2)) values are presented in Table $3\left(\mathrm{Cu}^{2+}\right.$ ions) and in Table 4
$\left(\mathrm{Zn}^{2+}\right.$ ions). Moreover, the nonlinearity in PDD courses for the crystals of size $L<40 \mu \mathrm{m}$ (in $\ln n-L$ coordinates, Fig. 2a-b) demonstrates the occurrence of a more complex process kinetics than it results from the assumptions constituting the SIG MSMPR model $[8,9]$. Considering this remark, the kinetic parameter values determined and demonstrated in Tables 3 and 4 should be regarded as rough estimates only. It especially


Fig. 2. Effect of $\mathrm{pH}$ and mean residence time $\tau$ in a continuous DT MSMPR crystallizer on population density distribution of crystal products: points - experimental data, solid lines - the $n(L)$ values calculated with Eq. (1), valid for crystal fraction $L>40 \mu \mathrm{m}$, dashed lines - linear extrapolations of SIG model for crystal fraction $0<L<40 \mu \mathrm{m}$ : a) $\mathrm{Cu}^{2+}$ ions (test Nos. 1, 6 and 8 in Tables 2 and 3); b) $\mathrm{Zn}^{2+}$ ions (test Nos. 1, 6 and 8 in Tables 2 and 4). 
concerns the nucleation rate values calculated with Eq. (2), based on the devaluated value of nuclei population density $n_{0}(n(L)$ for $L=0)$.

The presence of copper ions in a crystallizer feed affected nucleation and growth rates of struvite crystals advantageously. Increasing their concentration from 0.2 to $0.5 \mathrm{mg} \mathrm{Cu}{ }^{2+} / \mathrm{kg}$ of solution decreased that nuclei population density of struvite $n_{0}\left(6.978 \cdot 10^{16} \rightarrow 4.387 \cdot 10^{16}\right.$ $\left.1 /\left(\mathrm{mm}^{3}\right)\right)$, whereas their linear growth rate $G$ was slightly enlarged $\left(1.27 \cdot 10^{-8} \rightarrow 1.37 \cdot 10^{-8} \mathrm{~m} / \mathrm{s}\right.$ ) (Table 3). As a result (see Eq. (2)), the nucleation rate $B^{*}$ of struvite decreased $\left(8.9 \cdot 10^{8} \rightarrow 6.0 \cdot 10^{8} 1 /\left(\mathrm{sm}^{3}\right)\right.$. Thus the number of the smallest crystals in a product decreased, whereas a rise in the number and size of larger crystals was reported [10, 11]. The mean size of struvite crystals was enlarged by more than $6 \%$, from 27.5 to $29.3 \mu \mathrm{m}$ (Table 2). Zinc ions, however, affected the struvite reaction crystallization kinetics in an opposite manner to the effect of copper ions. The increase in feed concentration of $\mathrm{Zn}^{2+}$ from 0.2 to $2.0 \mathrm{mg} / \mathrm{kg}$ caused the nuclei population density of struvite $n_{0}$ to be raised clearly $\left(4.052 \cdot 10^{16} \rightarrow 6.924 \cdot 10^{16} 1 /\left(\mathrm{mm}^{3}\right)\right)$. At the same time, linear growth rate of crystals $G$ decreased $\left(1.43 \cdot 10^{-8} \rightarrow 1.24 \cdot 10^{-8} \mathrm{~m} / \mathrm{s}\right)$ (Table 4$)$. In such conditions, the resulting nucleation rate $B^{*}$ (see Eq. (2)) was enlarged by more than $45 \%\left(5.9 \cdot 10^{8} \rightarrow 8.6 \cdot 10^{8} 1 /\left(\mathrm{sm}^{3}\right)\right)$. In consequence, the mean size of struvite crystal product decreased from 31.4 to $23.1 \mu \mathrm{m}$, by more than $26 \%$ [12, 13] (Table 2).
In such defined process conditions, blocking of the available surface of growing struvite crystals by co-precipitating amorphous copper and zinc hydroxides (up to $90 \mathrm{mg} \mathrm{Cu} / \mathrm{kg}$ of the product [11] and up to $332 \mathrm{mg} \mathrm{Zn} \mathrm{/} \mathrm{kg}$ of the product [13]) was observed. Surface blocking induced tensions within the struvite crystals structures, which caused characteristic deformations. In scanning electron microscope images (Fig. 1a, b) some ruptures, deformed crystal edges, specific trough-like crystal forms, etc. can be observed. Instead of prismatic crystals, which are typical for struvite, some tubular solid forms dominated in a product. The individual effects of copper (Fig. 1a) or zinc (Fig. 1b) ions and their hydroxides on the growing struvite crystals caused their shapes, surfaces and edges to be clearly different. Increases in concentrations of zinc ions in a feed solution caused struvite crystal length $\left(L_{\mathrm{a}}\right)$-to-width $\left(L_{\mathrm{b}}\right)$ ratios to decrease from 8.3 to 7.0. Increasing the concentration of zinc ions made struvite crystal sizes shrink distinctly $[12,13]$. In contrast, copper ions did not modify the geometric relations in struvite crystals; $L_{\mathrm{a}} / L_{\mathrm{b}}$ was practically constant (ca. 6.6). In their presence, struvite crystallized similarly to products from aqueous solutions of phosphate(V) ions without impurities $[14,15]$. Mean $L_{\mathrm{a}} / L_{\mathrm{b}}$ value for 12 products manufactured in the presence of copper (Table 3) and zinc (Table 4) ions was 6.3 and 7.2, respectively. Thus, it was experimentally confirmed that independent of phosphate $(\mathrm{V})$ ions concentration

Table 4. Effect of zinc ions on struvite nucleation rate $B$ and crystal linear growth rate $G$ in a continuous reaction crystallization process; kinetic parameters calculated with SIG MSMPR model (for process conditions see Table 2).

\begin{tabular}{|c|c|c|c|c|c|c|}
\hline \multirow{3}{*}{ No. } & \multicolumn{6}{|c|}{ Kinetic parameter values of the process (SIG MSMPR model) } \\
\hline & $n(L)^{*}$ for $L>40 \mu \mathrm{m}$ & $\mathrm{R}^{2}$ & $L_{\mathrm{a}} / L_{\mathrm{bZn}}$ & $k_{\mathrm{v}}$ & $G$ & $B^{*}$ \\
\hline & & & - & - & $(\mathrm{m} / \mathrm{s})$ & $\left(1 /\left(\mathrm{sm}^{3}\right)\right)$ \\
\hline \multicolumn{7}{|c|}{ Molar proportion of substrate ions in a feed: $\left[\mathrm{PO}_{4}^{3-}\right]_{\mathrm{RM}}:\left[\mathrm{Mg}^{2+}\right]_{\mathrm{RM}}:\left[\mathrm{NH}_{4}^{+}\right]_{\mathrm{RM}}=1: 1: 1$} \\
\hline 1 & $n=4.052 \cdot 10^{16} \exp \left(-7.792 \cdot 10^{4} L\right)$ & 0.995 & 8.3 & 0.011 & $1.43 \cdot 10^{-8}$ & $5.9 \cdot 10^{8}$ \\
\hline 2 & $n=4.678 \cdot 10^{16} \exp \left(-7.939 \cdot 10^{4} L\right)$ & 0.998 & 7.6 & 0.014 & $1.40 \cdot 10^{-8}$ & $6.6 \cdot 10^{8}$ \\
\hline 3 & $n=6.924 \cdot 10^{16} \exp \left(-8.961 \cdot 10^{4} L\right)$ & 0.991 & 7.0 & 0.016 & $1.24 \cdot 10^{-8}$ & $8.6 \cdot 10^{8}$ \\
\hline 4 & $n=4.248 \cdot 10^{16} \exp \left(-8.715 \cdot 10^{4} L\right)$ & 0.995 & 7.6 & 0.014 & $1.27 \cdot 10^{-8}$ & $5.3 \cdot 10^{8}$ \\
\hline 5 & $n=6.518 \cdot 10^{16} \exp \left(-9.274 \cdot 10^{4} L\right)$ & 0.996 & 7.4 & 0.014 & $1.20 \cdot 10^{-8}$ & $7.9 \cdot 10^{8}$ \\
\hline 6 & $n=5.204 \cdot 10^{16} \exp \left(-8.896 \cdot 10^{4} L\right)$ & 0.993 & 6.6 & 0.018 & $1.25 \cdot 10^{-8}$ & $6.5 \cdot 10^{8}$ \\
\hline 7 & $n=1.850 \cdot 10^{17} \exp \left(-1.177 \cdot 10^{5} L\right)$ & 0.997 & 6.3 & 0.020 & $9.44 \cdot 10^{-9}$ & $1.7 \cdot 10^{9}$ \\
\hline 8 & $n=1.419 \cdot 10^{16} \exp \left(-5.760 \cdot 10^{4} L\right)$ & 0.987 & 6.0 & 0.022 & $4.82 \cdot 10^{-9}$ & $6.7 \cdot 10^{7}$ \\
\hline 9 & $n=1.424 \cdot 10^{16} \exp \left(-6.131 \cdot 10^{4} L\right)$ & 0.994 & 6.0 & 0.022 & $4.53 \cdot 10^{-9}$ & $6.3 \cdot 10^{7}$ \\
\hline 10 & $n=6.458 \cdot 10^{15} \exp \left(-7.338 \cdot 10^{4} L\right)$ & 0.994 & 8.0 & 0.012 & $1.51 \cdot 10^{-8}$ & $9.8 \cdot 10^{7}$ \\
\hline \multicolumn{7}{|c|}{ Molar proportion of substrate ions in a feed: $\left[\mathrm{PO}_{4}^{3-}\right]_{\mathrm{RM}}:\left[\mathrm{Mg}^{2+}\right]_{\mathrm{RM}}:\left[\mathrm{NH}_{4}{ }^{+}\right]_{\mathrm{RM}}=1: 1.2: 1$} \\
\hline 11 & $n=4.847 \cdot 10^{16} \exp \left(-8.172 \cdot 10^{4} L\right)$ & 0.999 & 7.5 & 0.014 & $1.36 \cdot 10^{-8}$ & $6.5 \cdot 10^{8}$ \\
\hline 12 & $n=6.040 \cdot 10^{15} \exp \left(-7.395 \cdot 10^{4} L\right)$ & 0.997 & 7.7 & 0.013 & $1.50 \cdot 10^{-8}$ & $9.0 \cdot 10^{7}$ \\
\hline
\end{tabular}

$*$ for $k_{\mathrm{v}}=1$

$\mathrm{R}^{2}$ for linear segment only 
Table 5. Comparison of kinetic parameters of struvite continuous reaction crystallization from wastewaters of different chemical composition; kinetic parameter values calculated with SIG MSMPR model; process parameters: temperature $298 \pm 0.2 \mathrm{~K}, \mathrm{pH} 9 \pm 0.1$, molar proportions of substrate ions in a feed $\mathrm{PO}_{4}^{3}: \mathrm{Mg}^{2+}: \mathrm{NH}_{4}{ }^{+}$as 1:1.2:1, mean residence time of suspension in a crystallizer $\tau 900 \pm 20 \mathrm{~s}$.

\begin{tabular}{|c|c|c|c|c|c|c|c|}
\hline \multirow{2}{*}{ Wastewater } & \multicolumn{4}{|c|}{ Feed: } & \multicolumn{3}{|c|}{ Kinetic parameters (SIG MSMPR model): } \\
\cline { 2 - 8 } & $\begin{array}{c}{\left[\mathrm{PO}_{4}{ }^{3-}\right]_{\mathrm{RM}}} \\
\mathrm{mass} \%\end{array}$ & $\begin{array}{c}{\left[\mathrm{Cu}^{2+}\right]_{\mathrm{RM}}} \\
\mathrm{mg} / \mathrm{kg}\end{array}$ & $\begin{array}{c}{\left[\mathrm{Zn}^{2+}\right]_{\mathrm{RM}}} \\
\mathrm{mg} / \mathrm{kg}\end{array}$ & $\begin{array}{c}k_{\mathrm{v}} \\
-\end{array}$ & $\begin{array}{c}n_{0}{ }^{*} \\
1 /\left(\mathrm{mm}^{3}\right)\end{array}$ & $\begin{array}{c}G \\
\mathrm{~m} / \mathrm{s}\end{array}$ & $\begin{array}{c}B^{*} \\
1 /\left(\mathrm{sm}^{3}\right)\end{array}$ \\
\hline SWW(a) & 0.20 & 0.25 & - & 0.018 & $3.9 \cdot 10^{15}$ & $1.63 \cdot 10^{-8}$ & $6.4 \cdot 10^{7}$ \\
\hline SWW(b) & 0.20 & - & 2.2 & 0.018 & $8.8 \cdot 10^{15}$ & $1.47 \cdot 10^{-8}$ & $1.3 \cdot 10^{8}$ \\
\hline SWW(c) & 0.445 & 0.25 & - & 0.018 & $7.1 \cdot 10^{15}$ & $1.54 \cdot 10^{-8}$ & $1.1 \cdot 10^{8}$ \\
\hline SWW(d) & 0.445 & - & 2.2 & 0.020 & $3.1 \cdot 10^{16}$ & $1.36 \cdot 10^{-8}$ & $4.2 \cdot 10^{8}$ \\
\hline SWW(e) & 0.445 & 0.25 & 2.2 & 0.020 & $2.1 \cdot 10^{16}$ & $1.40 \cdot 10^{-8}$ & $2.9 \cdot 10^{8}$ \\
\hline IWW & 0.445 & 0.25 & $2.2^{* *}$ & 0.033 & $2.5 \cdot 10^{16}$ & $1.43 \cdot 10^{-8}$ & $3.6 \cdot 10^{8}$ \\
\hline
\end{tabular}

$*$ for $k_{\mathrm{v}}=1$

** and $\mathrm{Al} 6.4, \mathrm{Ca} 440, \mathrm{~K} 46, \mathrm{Fe} 8.9$, Ti 0.2, $\mathrm{Si} 51, \mathrm{~F}^{-} 42, \mathrm{SO}_{4}{ }^{2-} 703 \mathrm{mg} / \mathrm{kg}$

in a feed, molar proportions of reagents, $\mathrm{pH}$ and mean residence time of suspension in a crystallizer, zinc ions influenced the struvite reaction crystallization process destructively. This all resulted in struvite crystals becoming shorter and thinner.

The decrease of phosphate( $\mathrm{V})$ ions concentration in a feed point (to 0.20 mass \%) influenced the kinetic parameters $\left(n_{0}^{*}, B^{*}\right.$ and $\left.G\right)$ of struvite continuous reaction crystallization advantageously (see test Nos. 1 and 10 in Table 3 and Nos. 2 and 10 in Table 4). Nuclei population density $n_{0}{ }^{*}$ decreased nearly 11 times (in the presence of copper ions) and more than 7 times (in the presence of zinc ions). Under such conditions, supersaturation of solution at the crystallizer inlet port decreased, thus nucleation rate $B^{*}$, strongly dependent on supersaturation, reflected this descending trend [8]: from $8.9 \cdot 10^{8}$ to $9.0 \cdot 10^{7} 1 /\left(\mathrm{sm}^{3}\right)$ and from $6.6 \cdot 10^{8}$ to $9.8 \cdot 10^{7} 1 /\left(\mathrm{sm}^{3}\right)$, respectively. Generating a lower number of nuclei in a crystallizer produced in effect larger size of product crystals (see Table 2). Despite a formal decrease of supersaturation at the crystallizer inlet port, linear crystal growth rate $G$ was enlarged (see Tables 3 and 4). To explain this, one should also consider also some specific properties of the SIG MSMPR model, whose kinetic parameters are calculated directly from the product crystal size distribution. However, the final sizes of struvite crystals represent some resulting net effect of different interactions - not only the supersaturation alone [14]. Thus, the net effect of all these interactions is clearly observable in the kinetic calculation results.

In the presence of both impurities, higher supersaturation of magnesium ions in a process system (molar ratio $\mathrm{PO}_{4}^{3-}: \mathrm{Mg}^{2+}: \mathrm{NH}_{4}^{+}$as 1:1.2:1) influenced partial components of struvite reaction crystallization kinetics advantageously. Nuclei population density $n_{0}{ }^{*}$ decreased, as well as nucleation rate $B^{*}$, whereas linear struvite crystal growth rate increased (comparing test Nos. 1 and 11, 10 and 12 in Table 3, as well as test Nos. 2 and 11, 10 and 12 in Table 4).
As a result, the mean size of product crystals enlarged (by $1.9 \mu \mathrm{m}$ in maximum; see Table 2) [11, 13]. It should be noticed that in aqueous solutions of phosphate(V) ions without impurities excess magnesium ions in respect to other ionic substrate concentrations influences the struvite reaction crystallization kinetics negatively [14]. Products of distinctly smaller size are removed from the crystallizer.

The $\mathrm{pH}$ exerts the essential effect on struvite reaction crystallization kinetics [3] (disadvantageous influence when raising), similar to mean residence time of suspension in a crystallizer working volume [14] (advantageous effect when elongating). Increased $\mathrm{pH}$ from 9 to 11, for $\tau 900 \mathrm{~s}$, results in a decrease of linear struvite crystal growth rate $G$ from $1.37 \cdot 10^{-8}$ to $9.88 \cdot 10^{-9} \mathrm{~m} / \mathrm{s}\left(0.5 \mathrm{mg} \mathrm{Cu}{ }^{2+} / \mathrm{kg}\right)$ and from $1.40 \cdot 10^{-8}$ to $9.44 \cdot 10^{-9} \mathrm{~m} / \mathrm{s}\left(0.5 \mathrm{mg} \mathrm{Zn}^{2+} / \mathrm{kg}\right)$. Nuclei population density $n_{0}{ }^{*}$, thus closely correlated with nucleation rate, enlarged from $6.0 \cdot 10^{8}$ to $1.4 \cdot 10^{9}$ $1 /\left(\mathrm{sm}^{3}\right)$ (Table 3) and from $6.6 \cdot 10^{8}$ to $1.7 \cdot 10^{9} 1 /\left(\mathrm{sm}^{3}\right)$ (Table 4), appropriately. As a consequence, the mean size of struvite crystals removed from the crystallizer decreased by $30-40 \%$ (Table 2). A comparison of the values demonstrated in Tables 3 and 4 shows that the disadvantageous action of $\mathrm{pH}$ parameter on the struvite reaction crystallization kinetics is practically identical and does not depend on the presence of the impurities tested. Elongation of mean residence time of suspension in a crystallizer from 900 to $3600 \mathrm{~s}$ confined nucleation rate of struvite significantly (for $\mathrm{pH}$ 9) from $6.0 \cdot 10^{8}$ to $1.1 \cdot 10^{8} 1 /\left(\mathrm{sm}^{3}\right)\left(0.5 \mathrm{mg} \mathrm{Cu} \mathrm{Cu}^{2+} / \mathrm{kg}\right)$ and from $6.6 \cdot 10^{8}$ to $6.3 \cdot 10^{7} 1 /\left(\mathrm{sm}^{3}\right)\left(0.5 \mathrm{mg} \mathrm{Zn}{ }^{2+} / \mathrm{kg}\right)$, thus more than 5 - and 10-times (Table 3 and Table 4, correspondingly). Linear crystal growth rate $G$, however, also decreased, but only 3 times. Devaluated nucleation rate, together with longer contact time with supersaturated mother solution, resulted in significant enlargement of mean struvite crystal size: up to ca. $40 \mu \mathrm{m}$ (Table 2).

Table 5, for comparison, presents the kinetic parameters of the struvite manufacturing process from 
six aqueous solutions of different chemical composition - termed as SWW(a) - SWW(e) - synthetic wastewater and IWW - industrial wastewater. All the research tests were run in an identical continuous DT MSMPR type crystallizer. Also, technological parameters of its work were the same: $\mathrm{PO}_{4}^{3-}: \mathrm{Mg}^{2+}: \mathrm{NH}_{4}^{+}=1: 1.2: 1, \mathrm{pH} 9, \tau 900$ s, process temperature $T 298 \mathrm{~K}$. SWW(a) and $\mathrm{SWW}(\mathrm{b})$ are synthetic wastewaters of the following composition: 0.20 mass $\%$ of $\mathrm{PO}_{4}^{3-}$ and $0.25 \mathrm{mg} \mathrm{Cu}{ }^{2+} / \mathrm{kg}$, as well as 0.20 mass $\%$ of $\mathrm{PO}_{4}^{3-}$ and $2.2 \mathrm{mg} \mathrm{Zn}^{2+} / \mathrm{kg}$, correspondingly. SWW(c) and SWW(d) represent aqueous solutions of phosphate( $\mathrm{V})$ ions (0.445 mass $\%)$ and copper ions $\left(0.25 \mathrm{mg} \mathrm{Cu} \mathrm{Cu}^{2+} / \mathrm{kg}\right)$ or zinc ions

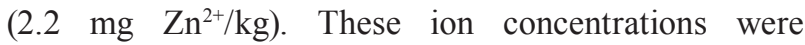
purposefully selected matching the phosphate(V), copper and zinc ion concentrations in real wastewater from phosphorus mineral fertilizer industry IWW [2]. Also, some research tests on reaction crystallization of struvite from the solution of composition (like in IWW wastewater) were done: 0.445 mass $\%$ of $\mathrm{PO}_{4}^{3-}$, $0.25 \mathrm{mg} \mathrm{Cu} \mathrm{Cu}^{2+} / \mathrm{kg}$ and $2.2 \mathrm{mg} \mathrm{Zn}^{2+} / \mathrm{kg}$ (as $\mathrm{SWW}(\mathrm{e})$ ). A kinetic data comparison shows that chemical composition of wastewater affected the struvite continuous reaction crystallization run significantly. The most advantageous conditions for its reaction crystallization (relatively small $B^{*}$, possibly high $G$ ) were observed for SWW(a) wastewater, while the worst ones were for SWW(d) wastewater. Reaction crystallization of struvite from the SWW(d) wastewater corresponded to nearly an 8-time increase in nuclei population density $n_{0}^{*}$, a 6.5 -time rise in nucleation rate $B^{*}$, as well as nearly a $17 \%$ decrease of linear growth rate $G$, compared to these parameter values for SWW(a) wastewater (see Table 5). One can assume that the possibly reason for such large differences is the presence of zinc ions in a process system, together with their high concentration: $2.2 \mathrm{mg} \mathrm{Zn}{ }^{2+} / \mathrm{kg}$ of feed solution. Also, a comparison of the kinetic parameters of continuous struvite reaction crystallization from IWW wastewater and from SWW(c), SWW(d) and SWW(e) synthetic wastewaters seems to be interesting. The concentration of phosphate $(\mathrm{V})$ ions in all compared wastewaters was identical (0.445 mass $\%$ of $\left.\mathrm{PO}_{4}^{3-}\right)$. Concentrations of copper ions in SWW(c) wastewater $\left(0.25 \mathrm{mg} \mathrm{Cu}{ }^{2+} / \mathrm{kg}\right)$, zinc ions in $\mathrm{SWW}(\mathrm{d})$ wastewater $\left(2.2 \mathrm{mg} \mathrm{Zn}{ }^{2+} / \mathrm{kg}\right)$, and concentrations of both these ions in SWW(e) wastewater were identical as in IWW industrial wastewater. However, the IWW industrial wastewater also contained aluminium, calcium, potassium, iron, titanium, fluoride, sulphate(VI) ions and soluble silicon compounds (see Table 5). The presence of copper ions only $\left(0.25 \mathrm{mg} \mathrm{Cu}{ }^{2+} / \mathrm{kg}\right)$ caused linear growth rate of struvite crystals to be $1.54 \cdot 10^{-8} \mathrm{~m} / \mathrm{s}$ (SWW(c)), thus it was the highest from within the three compared values. In the presence of zinc ions $\left(2.2 \mathrm{mg} \mathrm{Zn}^{2+} / \mathrm{kg}\right)$ this rate decreased to $1.36 \cdot 10^{-8} \mathrm{~m} / \mathrm{s}(\mathrm{SWW}(\mathrm{d}))$ and this time it was the smallest within the three values under comparison. The simultaneous presence of both ionic impurities (SWW(e)) produced in net effect $G$
$1.40 \cdot 10^{-8} \mathrm{~m} / \mathrm{s}$. Although this value was higher than the struvite growth rate in the presence of zinc ions only $(\mathrm{SWW}(\mathrm{d}))$, it was lower than the growth rate corresponding to the presence of copper ions only (SWW(c)). The co-presence of all mentioned impurities accompanying phosphate $(\mathrm{V})$ ions in industrial wastewater IWW produced linear growth rate of struvite crystals that was not the smallest from within all compared values (it was $1.43 \cdot 10^{-8} \mathrm{~m} / \mathrm{s}$ ). It was higher by ca. 3\% than corresponding $G$ observed in wastewater solution covering both copper and zinc ions - SWW(e). Additional impurities co-present in industrial wastewater IWW thus influenced the process advantageously. After recalculating the $B^{*}$ values from Table 5 (considering the effect of crystal shape coefficient $k, B=B^{*} / k_{\mathrm{v}}$ ), it turned out that the highest struvite nucleation rate corresponded to solution, for which growth rate was the smallest: SWW(d). Moreover, the $B$ values for the wastewaters containing 0.445 mass $\%$ of $\mathrm{PO}_{4}{ }^{3-}$ can be ordered in the following sequence (in $1 /\left(\mathrm{sm}^{3}\right)$ ): $3.6 \cdot 10^{9}$ $(\mathrm{SWW}(\mathrm{a}))<6.1 \cdot 10^{9}(\mathrm{SWW}(\mathrm{c}))<7.2 \cdot 10^{9}(\mathrm{SWW}(\mathrm{b}))<$ $1.1 \cdot 10^{10}(\mathrm{IWW})<1.5 \cdot 10^{10}(\mathrm{SWW}(\mathrm{e}))<2.1 \cdot 10^{10}(\mathrm{SWW}(\mathrm{d}))$. From the comparison it also results that struvite nucleation in industrial wastewater was lower than in the presence of zinc ions only or copper and zinc ions only, which may demonstrate the advantageous action of other impurities co-present in this wastewater on the restriction of struvite nucleation. Some form of experimental confirmation of the significant influence of impurities on all components of this process may be a comparison of the quality of products manufactured from wastewater without impurities [16] and from industrial wastewater IWW [2]. From the crystallizer fed with industrial wastewater we removed product of better quality. Struvite crystals were better shaped and more size-homogeneous (mean crystal size $L_{\mathrm{m}} 34.2 \mu \mathrm{m}$, coefficient of crystal size variation CV $80.9 \%$ [2]) than solid products manufactured from solution of phosphate(V) ions without impurities $\left(L_{\mathrm{m}} 28.6 \mu \mathrm{m}, \mathrm{CV} 87.3 \%\right.$ [16]).

\section{Conclusions}

Kinetic parameters of continuous struvite reaction crystallization process in aqueous solutions containing phosphate $(\mathrm{V})$ ions and selected impurities (copper or/ and zinc ions) were estimated. It was experimentally demonstrated that the presence of copper ions influenced the process course advantageously. Increased concentrations of these ions in a crystallizer feed from 0.2 to $0.5 \mathrm{mg} \mathrm{Cu}{ }^{2+} / \mathrm{kg}$ caused linear struvite crystal growth rate to be enlarged by ca. $8 \%$ : from $1.27 \cdot 10^{-8}$ up to $1.37 \cdot 10^{-8} \mathrm{~m} / \mathrm{s}$, whereas nucleation rate decreased by as much as ca. $33 \%$. In contrast, the zinc ions influenced the struvite reaction crystallization process kinetics disadvantageously. Increases in inlet concentration of this impurity from 0.2 to $2.0 \mathrm{mg} \mathrm{Zn}^{2+} / \mathrm{kg}$ caused a rise in nucleation rate from $5.9 \cdot 10^{8}$ to $8.6 \cdot 10^{8} 1 /\left(\mathrm{sm}^{3}\right)$, 
simultaneously decreasing crystal growth rate from $1.43 \cdot 10^{-8}$ to $1.24 \cdot 10^{-8} \mathrm{~m} / \mathrm{s}$. This represents a relatively large drop of $G$, by more than $13 \%$. Mean size of product crystals decreased by more than $26 \%$ - from 31.4 to $23.1 \mu \mathrm{m}$.

Differences in both impurity interactions with struvite continuous reaction crystallization kinetics are also visible during $\mathrm{pH}$ rise and elongation of mean residence time of suspension in a crystallizer. In general, increases in $\mathrm{pH}$ from 9 to 11 produced for both impurities - increases in nucleation rate and decreases of linear struvite crystal growth rate. Fourtime elongation of mean residence time of suspension produced a decrease of both kinetic parameters of the reaction crystallization process $(B, G)$.

Moreover, we concluded that lower concentrations of phosphate(V) ions in a feed, as well as excess (20\%) of magnesium ions in respect to phosphate( $\mathrm{V})$ and ammonium ion concentrations in a process system, influenced nucleation and growth of struvite crystals advantageously. Lower nucleation rates and higher crystal linear growth rates were observed. Moreover, we concluded that the co-presence of other impurities in a process environment affects nucleation and growth of struvite crystals advantageously and compensates in this range disadvantageous action of zinc ions.

$B$ - nucleation rate, $\mathrm{m}^{-3} \mathrm{~s}^{-1}$

$B^{*}$ - nucleation rate considering effect of crystal shape coefficient $k_{\mathrm{v}}, B=B^{*} / k_{\mathrm{v}}$

$\left[\mathrm{Cu}^{2+}\right]_{\mathrm{RM}}$ - feed concentration of $\mathrm{Cu}^{2+}$ ions, $\mathrm{mg} / \mathrm{kg}$

$\mathrm{CV}$ - coefficient of crystal size variation, $\%$

$\mathrm{CV}{ }_{\mathrm{Cu}}-$ coefficient of crystal size variation in presence of $\mathrm{Cu}, \%$

$\mathrm{CV}_{\mathrm{Zn}}-$ coefficient of crystal size variation in presence of $\mathrm{Zn}, \%$

$G$ - linear crystal growth rate, $\mathrm{ms}^{-1}$

$k_{\mathrm{v}}$ - crystal shape coefficient, -

$L$ - crystal size, $\mathrm{m}$

$L$ - crystal length, $\mathrm{m}$

$L_{\mathrm{b}}^{\mathrm{a}}$ - crystal width, $\mathrm{m}$

$L_{\mathrm{m}}$ - mean crystal size, $\mathrm{m}$

$L_{\mathrm{m} \mathrm{Cu}}-$ mean crystal size in presence of $\mathrm{Cu}, \mathrm{m}$

$L_{\mathrm{m} \mathrm{Zn}}$ - mean crystal size in presence of $\mathrm{Zn}, \mathrm{m}$

$L_{84}, L_{16}, L_{50}-$ crystal sizes corresponding to: 84,16 and 50 mass $\%$ undersize fractions in cumulative distribution, $m$

$M_{\mathrm{T}}-$ solid phase content in a product suspension, $\mathrm{kg}_{\text {solid }}$ $\mathrm{m}^{-3}$

$n(L)$ - population density corresponding to crystal size $L, \mathrm{~m}^{-1} \mathrm{~m}^{-3}$

$n_{0}-$ nuclei population density, $\mathrm{m}^{-1} \mathrm{~m}^{-3}$

$n_{0}{ }^{*}$ - nuclei population density calculated assuming $k_{\mathrm{v}}=1, \mathrm{~m}^{-1} \mathrm{~m}^{-3}$

$\left[\mathrm{PO}_{4}{ }^{3-}\right]_{\mathrm{RM}}$ - feed concentration of phosphate $(\mathrm{V})$ ions, mass \%

$T$ - process temperature, $\mathrm{K}$

$\tau$ - mean residence time of suspension in a crystallizer, $\mathrm{s}$
$V_{\text {crystal }}$ - crystal volume, $\mathrm{m}^{3}$

$\left[\mathrm{Zn}^{2+}\right]_{\mathrm{RM}}$ - feed concentration of $\mathrm{Zn}^{2+}$ ions, $\mathrm{mg} / \mathrm{kg}$

$x_{\mathrm{i}}$ - mass fraction of crystals of mean fraction size $L_{\mathrm{i}}$,

\section{Abbreviations}

CSD - Crystal Size Distribution

DT - Draft Tube

IWW - Industrial Wastewater

MAP $-\mathrm{MgNH}_{4} \mathrm{PO}_{4} \cdot 6 \mathrm{H}_{2} \mathrm{O}$, struvite

MSMPR - Mixed Suspension Mixed Product Removal

(crystallizer)

PDD - Population Density Distribution

SIG - Size-Independent Growth (kinetic model)

SWW - Synthetic Wastewater

\section{Acknowledgements}

Our work was supported by the National Science Centre of Poland under grant No. 2016/21/D/ST8/01694, 2017-2020.

\section{Conflict of Interest}

The authors declare no conflict of interest.

\section{References}

1. BECKER P. Phosphates and Phosphoric Acid, Raw Materials, Technology and Economics of the Wet Process; Marcel Dekker: New York, USA; 1999.

2. HUTNIK N., KOZIK A., MAZIENCZUK A., PIOTROWSKI K., WIERZBOWSKA B., MATYNIA A. Phosphates(V) recovery from phosphorus mineral fertilizers industry wastewater by continuous struvite reaction crystallization process. Wat. Res., 47, 3635, 2013.

3. DOYLE J.D., PARSONS S.A. Struvite formation, control and recovery. Wat. Res., 36, 3925, 2002.

4. LE CORRE K.S., VALSAMI-JONES E., HOBBS P., PARSONS S.A. Phosphorus recovery from wastewater by struvite crystallization: a review. Crit. Rev. Environ. Sci. Technol., 39, 433, 2009.

5. KOZIK A., HUTNIK N., PIOTROWSKI K. MAZIENCZUK A., MATYNIA A. Precipitation and crystallization of struvite from synthetic wastewater at the magnesium ions excess. Przem. Chem., 93, 756, 2014 [In Polish].

6. RAHMAN M.M., SALLEH M.A.M., RASHID U., AHSAN A., HOSSAIN M.M., RA C.S. Production of slow release crystal fertilizer from wastewaters through struvite crystallization - A review. Arabian J. Chem., 7, 139, 2014

7. LATIFIAN M., LIU J., MATTIASSON B. Struvite-based fertilizer and its physical and chemical properties. Environ. Technol., 33, 2691, 2012.

8. MULLIN J.W. Crystallization, Butterworth-Heinemann, Oxford, England, 1993. 
9. RANDOLPH A.D., LARSON M.A. Theory of Particulate Processes: Analysis and Techniques of Continuous Crystallization, Academia Press, New York, USA, 1988.

10. HUTNIK N., MATYNIA A., PIOTROWSKI K., MAZIENCZUK A. Influence of copper ions on the quality of struvite crystals produced in continuous reaction crystallization process. In Proceedings of $38^{\text {th }}$ International Conference of Slovak Society of Chemical Engineering. Tatranské Matliare, Slovakia; 2011; Markoš J. Ed., 318, 2011.

11. HUTNIK N., WIERZBOWSKA B., PIOTROWSKI K., MATYNIA A. Effect of copper(II) ions on quality of struvite produced in continuous reaction crystallization process at the magnesium ions excess. Adv. Chem. Eng. Sci., 3, 1, 2013.

12. HUTNIK N., WIERZBOWSKA B., PIOTROWSKI K., MATYNIA A. Effect of continuous crystallizer performance on struvite crystals produced in reaction crystallization from solutions containing phosphate(V) and zinc(II) ions. Brazilian J. Chem. Eng., 33, 307, 2016.
13. HUTNIK N., KOZIK A., WIERZBOWSKA B., MATYNIA A. Effect of zinc ions on quality of struvite. Przem. Chem., 94, 1609, 2015 [In Polish].

14. KOZIK A., HUTNIK N., PIOTROWSKI K., MATYNIA A. Continuous reaction crystallization of struvite from diluted aqueous solution of phosphate( $\mathrm{V})$ ions in the presence of magnesium ions excess. Chem. Eng. Res. Des., 92, 481, 2014.

15. KOZIK A., MATYNIA A., HUTNIK N., PIOTROWSKI $\mathrm{K}$. Effect of technological input parameters on struvite separation in a continuous laboratory plant. Przem. Chem., 92, 796, 2013 [In Polish].

16. HUTNIK N., KOZIK A., WIERZBOWSKA B., PIOTROWSKI K. Effect of aluminum ions on struvite continuous reaction crystallization kinetics. In Proceedings of the $43^{\text {rd }}$ International Conference of Slovak Society of Chemical Engineering. Tatranské Matliare, Slovakia; 2016; Markoš J. Ed., 528, 2016. 
